\title{
Research Paper \\ Comparison of the Coherence and Defense Mechanisms between Parents of Normal Children and Parents of Children with Autism andAttention Deficit Hyperactivity Disorder
}

\author{
Elham Taati ${ }^{1}$, Mohammad Reza Zarbakhsh Bahri ${ }^{* 2}$ \\ 1. M.A. Student of Clinical Psychology, Tonekabon Branch, Islamic Azad University, Tonekabon, Iran \\ 2. Assistant Professor, Department of Clinical Psychology, Tonekabon Branch, Islamic Azad University, Tonekabon, Iran
}

Citation: Taati E, Zarbakhsh Bahri MR. Comparison of the coherence and defense mechanisms between parents of normal children and parents of children with autism and attention deficit hyperactivity disorder. Quarterly Journal of Child Mental Health. 2019; 6(3): 15-27.

http://dx.doi.org/10.29252/jcmh.6.3.3

\section{A R T I C L E I N F O}

\section{Keywords:}

Coherence,

defense mechanisms, autism, attention deficit hyperactivity disorder

Received: 12 Jan 2018

Accepted: 27 Mar 2018

Available: 9 Nov 2019

\section{A B S T R A C T}

Background and Purpose: Certain childhood psychological disorders such as autism and attention deficit hyperactivity disorder result in significant psychological damages to parents. Based on the results of different studies, various problems in these children, cause anxiety and stress in their family members. Hence, this study was conducted to compare the coherence and defense mechanisms among the parents of normal children and parents of children with autism and attention deficit hyperactivity disorder.

Method: This study was a descriptive and causal-comparative design. The statistical population included all parents of normal children and parents of children with autism and attention deficit hyperactivity disorder in Rasht city in 2016-2017. The sample size of the study consisted of 90 parents who were selected by convenience sampling and based on inclusion and exclusion criteria. Defense Style Questionnaire (Andrews et al., 1993) and Sense of Coherence (Antonovsky, 1987) were used to measure the variables. The data were analyzed by multivariate analysis of variance.

Results: The results of the study indicated that there was a significant difference among the three groups of parents of normal children and parents of children with autism and attention deficit hyperactivity disorder in each component of coherence $(\mathrm{p}<0.05)$. Parents of children with attention deficit hyperactivity disorder had the lowest mean score in coherence (90.96), while the highest score (101.93) was for the group of parents with normal children. There was a significant difference between the three groups of parents in each component of defense mechanism $(p<0.05)$.

Conclusion: Based on the results of the current research, parents of normal children and parents of children with autism and attention deficit hyperactivity disorder experience higher levels of mental stresses related to parenting, which may be caused by the special needs of these children and the distinctive psychological and mental differences between them and their peers. In this way, planning and implementing appropriate psychological and educational interventions for the parents of these children, with an emphasis on the initial interventions, can be very helpful.

\footnotetext{
* Corresponding author: Mohammad Reza Zarbakhsh Bahri, Assistant Professor, Department of Clinical Psychology, Tonekabon Branch, Islamic Azad University, Tonekabon, Iran.

E-mail addresses: Rzarbakhsh@yahoo.com
} 


\section{مقايسه انسجام روانى و مكانيسمهاى دفاعى در والدين داراى كودك با اختلال طيف اوتيسم، نارسايى توجه / فزون كنشى، و بهنجار}

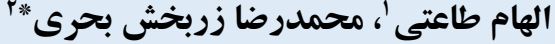

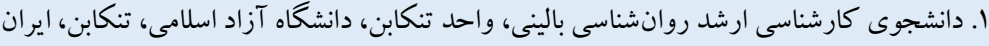

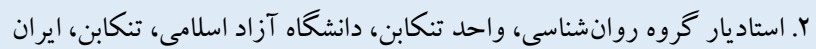

\section{جكيله}

زمينه و هدف: بعضى از اختلالهاى روانشناختى دوران كودكى مانند اختلال طيف اوتيسم و نارسايى توجه/فزون كنشى، آسيبهاى روانشناختى معنادارى را براى والدين به همراه دارند. بر اساس نتايج مطالعات مختلف، مشكلات متعدد اين كودكان، اعضاى خانواده را دجهار آشفتگى و تنيدگى زيادى مى كنند؛ بدين ترتيب يُزوهش حاضر بهمنظور مقايسه انسجام روانى و مكانيسمهاى دفاعى در والدين داراى برى كو دك مبتلابه اختلال طيف اوتيسم، نارسايى توجه/فزون كنشى، و بهنجار انجام شد. روش: طرح يزوهش توصيفى از نوع على - مقايسهاى بود. جامعه آمارى بثوهش شامل تمامى والدين داراى كودكى با اختلال طيف اوتيسم،

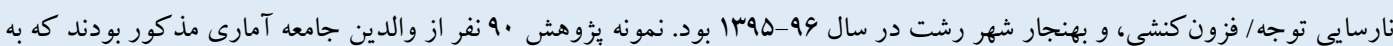

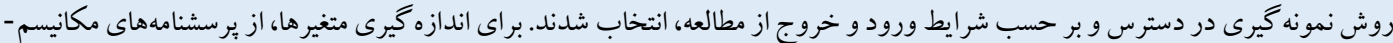
هاى دفاعى (آندروز و همكاران، سوان (199) و حس انسجام (آنتونووسكى، 19AV) استفاده شد. تحليل دادههاى به دست آمده با آزمون تحليل واريانس جندمتغيرى انجام شد. يافته ها: نتايج ئزوهش نشان داد بين سه گروه والدين داراى كودكك با اختلال طيف اوتيسم، نارسايى توجه/ فزون كنشى، و بهنجار در هر

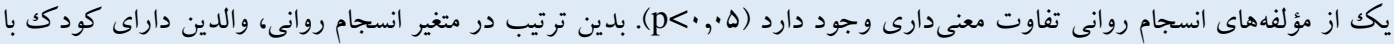

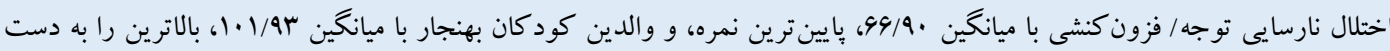

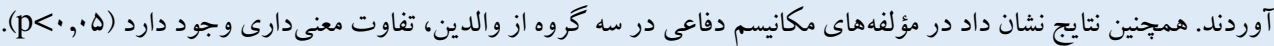
نتيجه كيرى: بر اساس نتايج يثوهش حاضر، والدين داراى كود كان مبتلابه اختلالات طيف اوتيسم و نارسايى توجه/فزون كنشى، سطوح

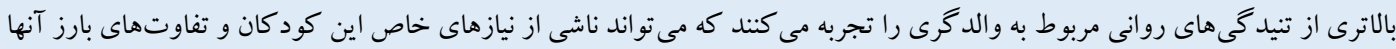

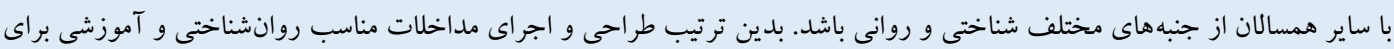

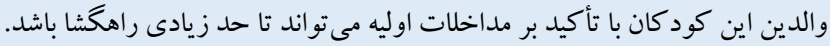

مشخصات مقاله

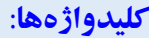

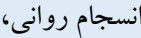
مكانيسم هاى دفاعى،

اختلال طيف اوتيسم، نارسايى توجه / فزون كنشى

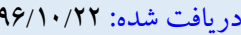

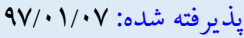
منتشر شده: M

* نويسنده مسئول: محمدرضا زربخش بحرى، استاديار گروه روانشناسى، واحد تنكابن، دانشكاه آزاد اسلامى، تنكابن، ايران.

راياناهם: Rzarbakhsh@yahoo.com

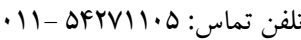


نشـان داده شـــ كه رفتارهاى سـازشـى كود كان با اختلال طيف اوتيسـم

مقدمه

ارتباط تنگ汭范 با سلامت روانى والدين دارد (4).

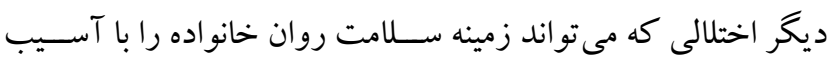

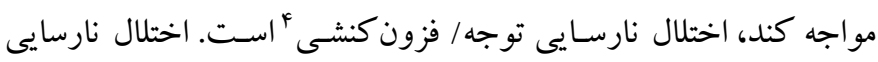

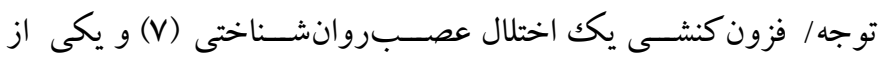
رايجتريسن اختلالهــاى عصبـى -تحولى دوران كودكـى اسـتـ ايسن

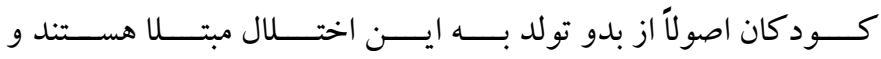

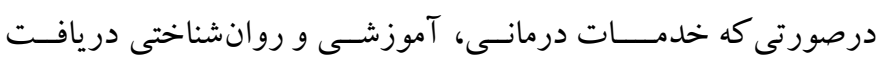

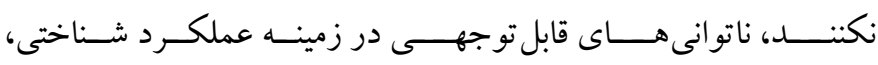

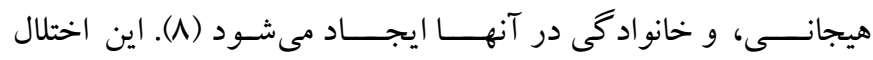

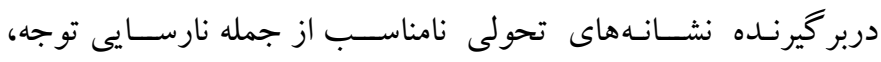

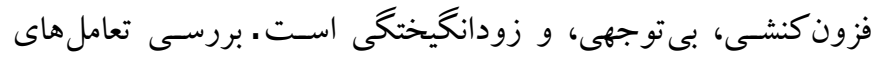

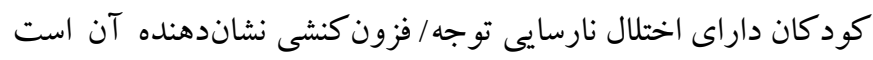

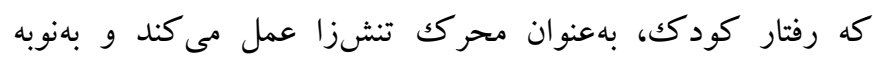
خود بر رفتار والد و تعامل ميان والد بهويزه مادر و كودكك مؤثر است (9). كود كان مبتلابه اختلال نارسايى توجه/ فزون كنشى در مقايسه

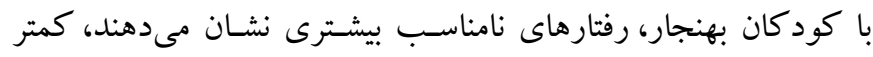

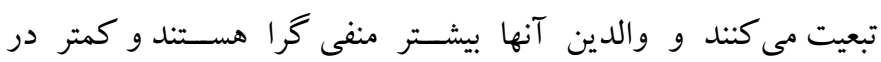

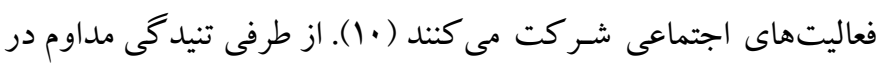

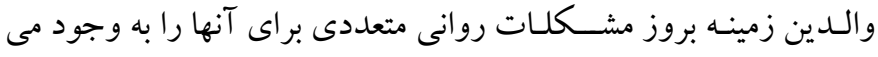
آورد. لين، اورسماند، كاستر و كوهن (11) در ثئوهشى نشان دادهاند كه

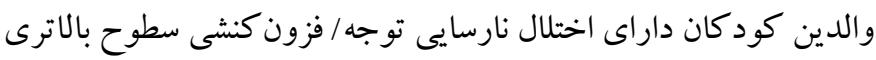

$$
\text { از اختلالات شخصيتى و افسردگى را دارا هستند. }
$$

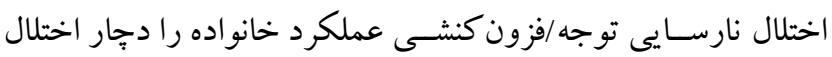
مى كند، زيرا والدين از مشكلات روانشناختى بيشترى رنج مى برند و در

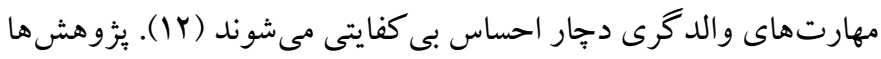

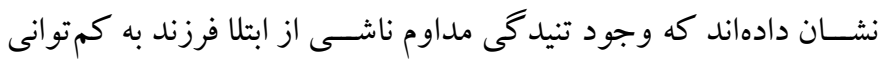
ذهنى، احتمال بروز علائم و حتى اختلالات شخصيتى در والدين كود كان

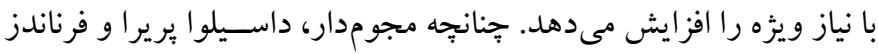

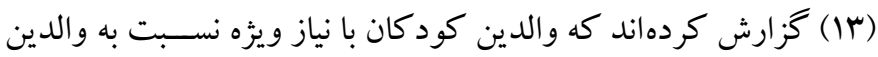

اختلال هاى عصبى تحولى'، يكى از انواع اختلالات دوره كودكى هستند

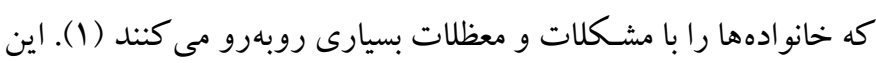

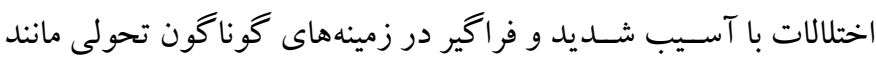
اختلـال در مهارتهاى تعامل اجتماعى متقابل و مهارت هاى ارتباطى و يا وجود رفتار و علايق و فعاليتهاى كليشـهاى مشـخص مى شــوند. اختلال

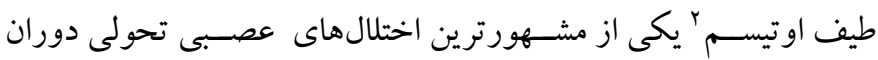

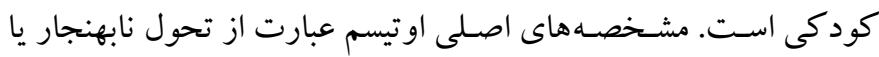

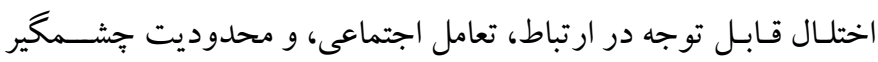
فعاليتها و علايق اسـت. جلوههاى اين اختلال با توجه به سـطح تحول و

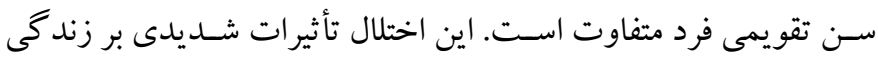

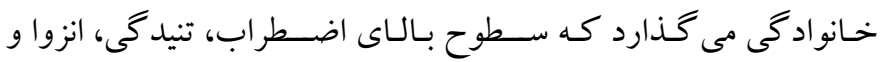
بلاتكليفى در والدين و همجنين كاهش رضـايت زناشـويى بهخصــوص

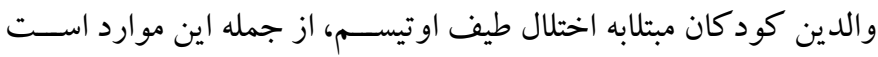

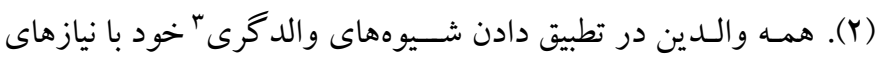

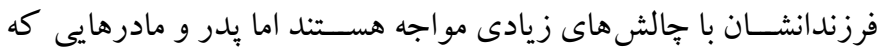

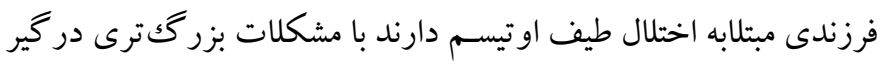
هستند كه با مشكلات يُرورش كود كان بهنجار قابل مقايسه نيست. تعامل

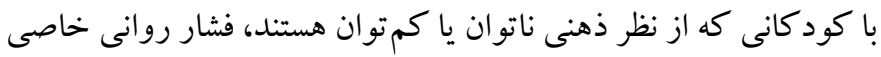
را بر والـدين و بـهويزه مـادران و كل خانو اده تحميل مى كند كه به به دنبال

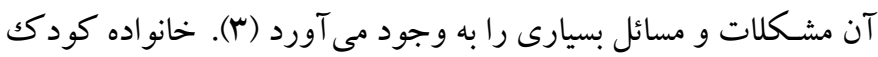
با نياز ويزه، به لحاظ داشتن كودكى متفاوت از ساير كود كان با مشكلات

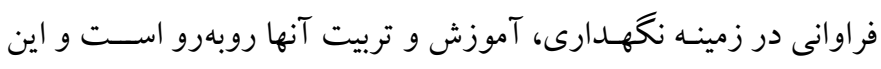
مسائل همخى بر والدين تنيدگى خاصى راو وارد مى كنند كه سبب برهم

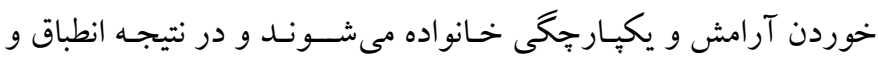

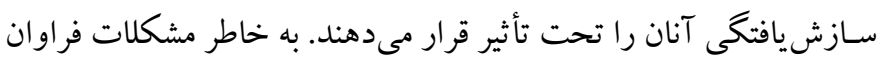

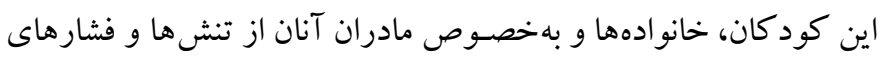

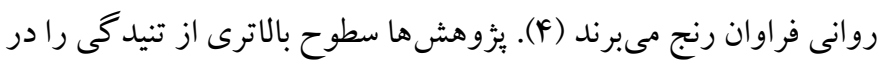

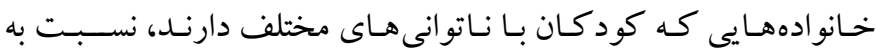
خانو ادههايى كه كود كك بهنجار دارند، گزارش كردهاند (ه). در يثزوهشى 
فيشـر و دوان (·r) نيز گزارش كردهاند كه مادران كود كان اسـتثنائى در

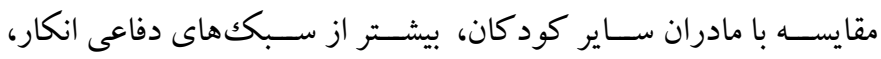

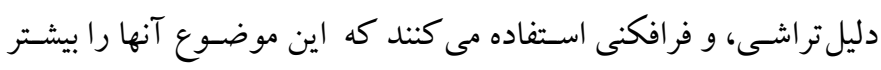

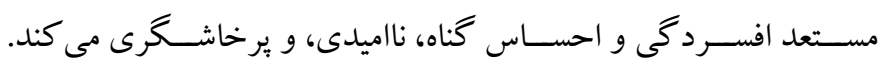

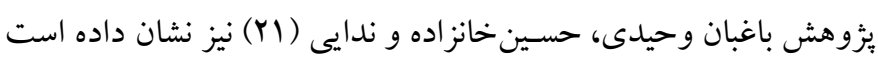

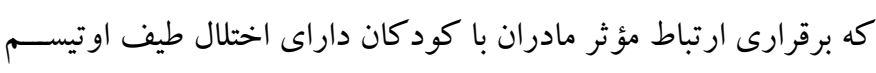

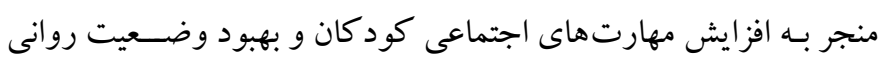
مادران مىشود.

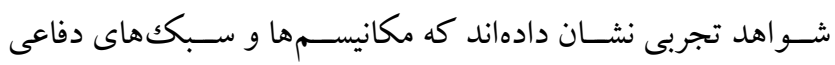

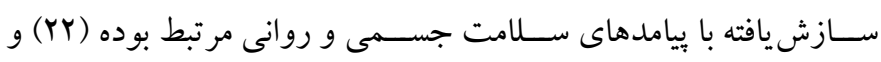

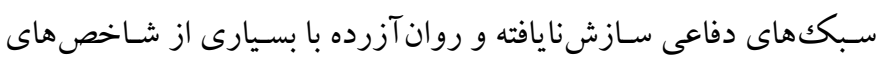

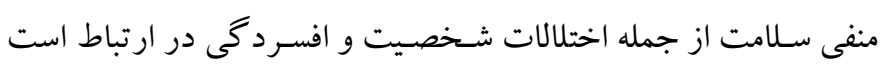

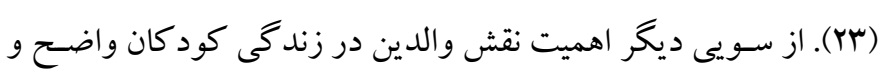

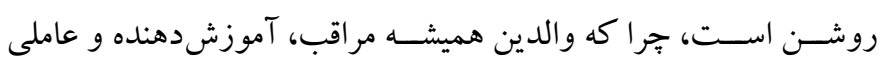

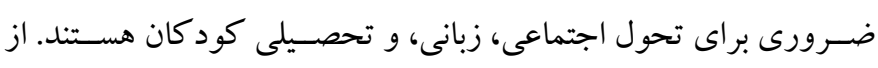

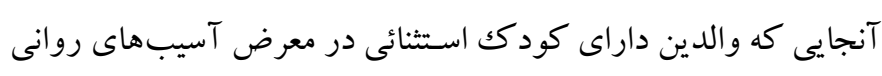

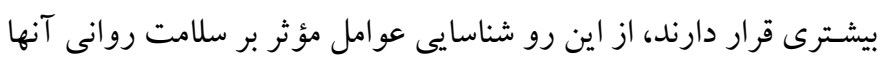

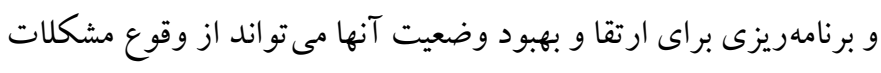

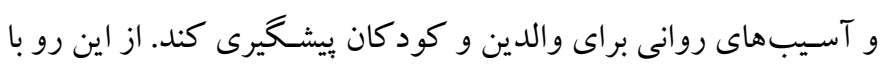

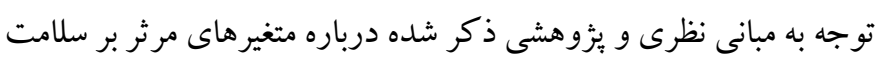

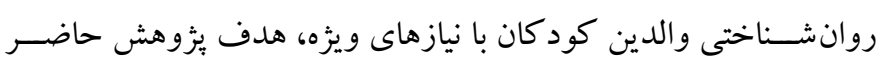

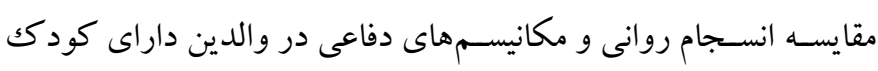

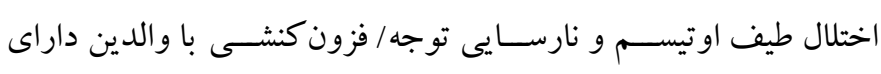

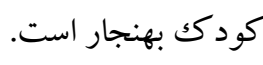

\section{روش طرح}

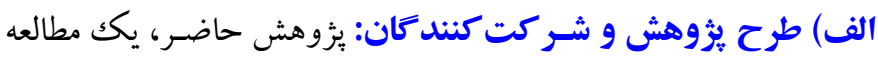

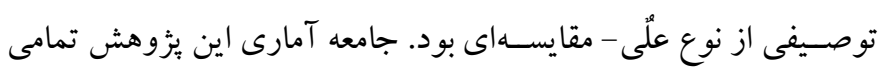

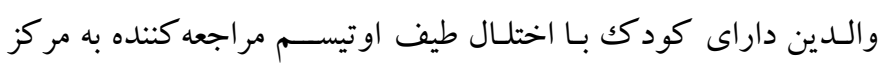

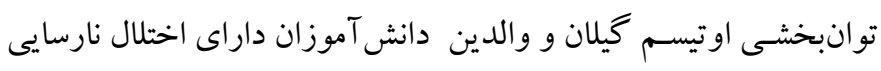

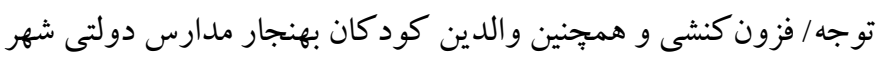

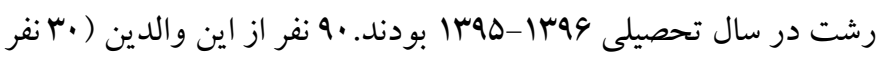

كود كان بهنجار از اضطراب و تنيدگى بيشترى برخوردار هستند. همجنين

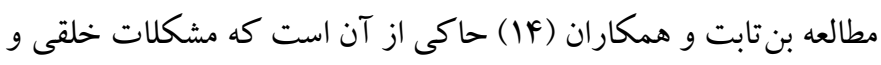

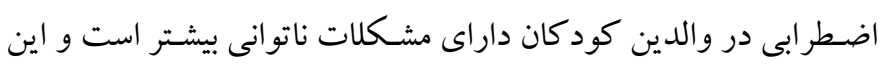

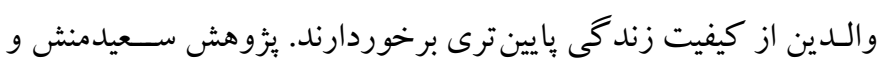

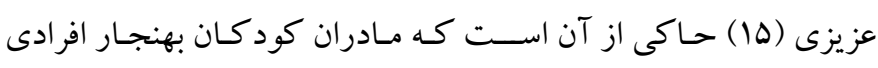

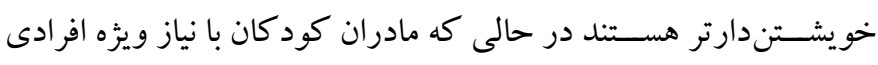

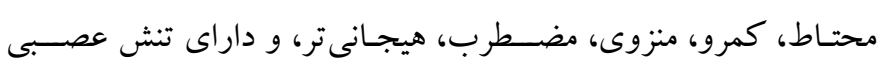
بيشترى هستند.

همه يدرها و مادرها دوسـت دارند كه كودكى سـالم و موفق داشـهـ

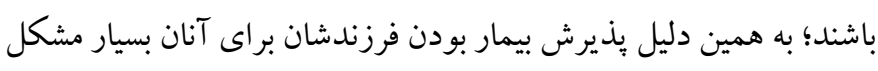

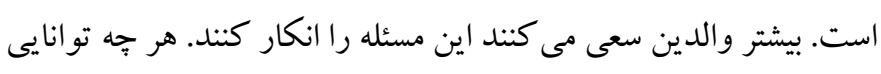

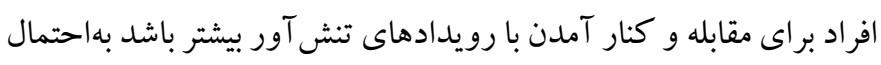

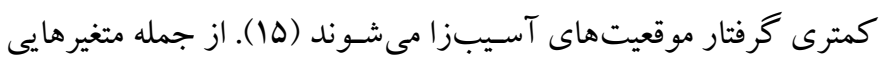
كه بهصورت هوشيار و ناهوشيار سطح يردازش شناختى و هيجانى والدين

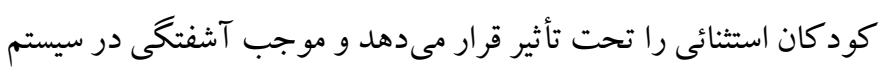

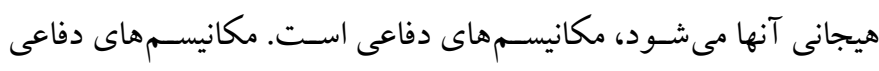

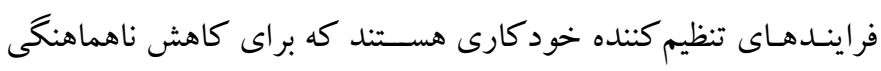

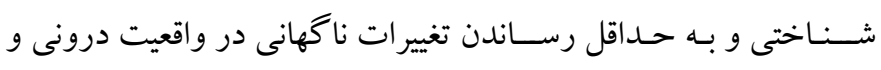

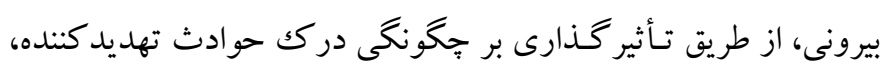

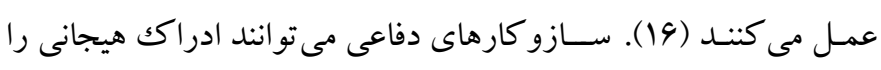
تحريف كرده و تغيير دهند، زيرا توجه و دقت ما را به واقعيت تحريف و و واني

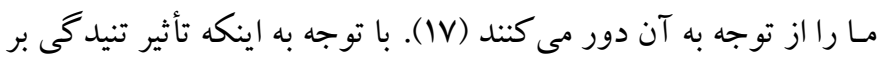

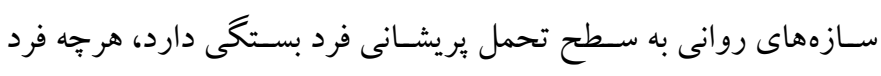

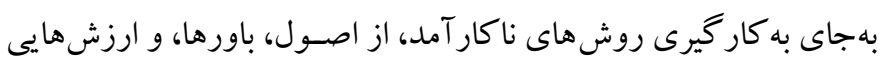

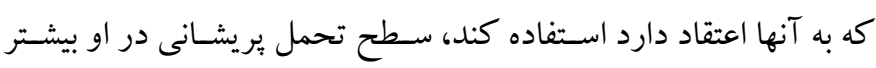
خواهد بود (1)). نتايج بثزوهش عباسى و بيرانى (19) نشان داد كه والدين

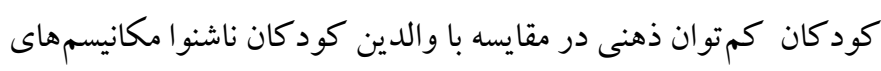

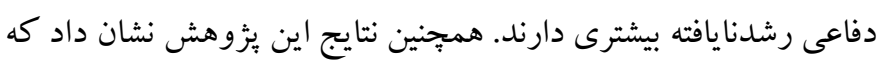
جنسيت در استفاده از مكانيسمهاى دفاعى رشدنايافته تفاوتى ايجاد نكرد.

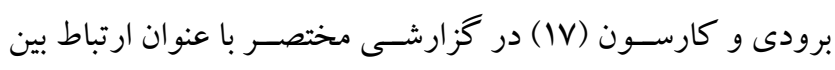

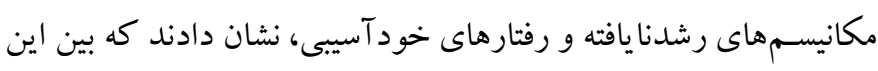

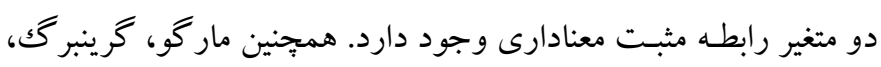


رشــنايافته شـامل مواردى از قبيل دليلتراشـى، فرافكنى، انكار، همه

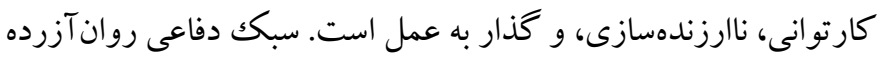

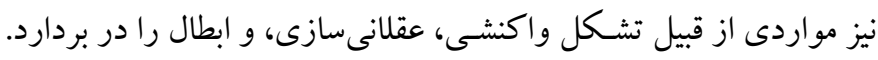

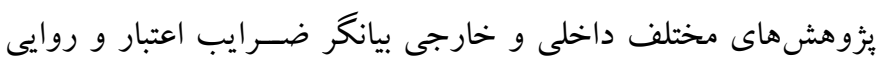

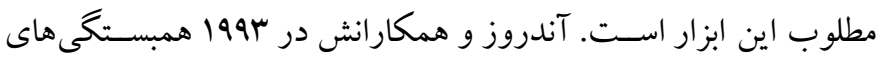

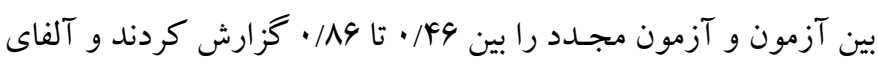

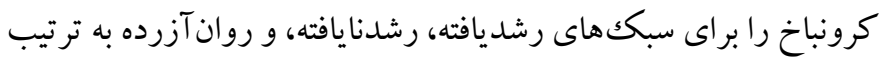

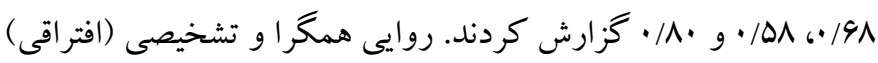

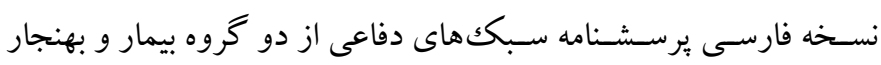

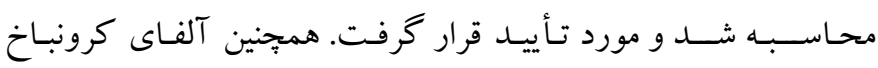

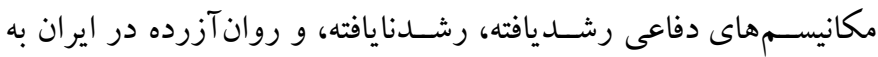

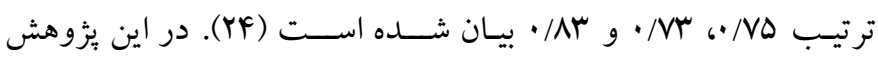

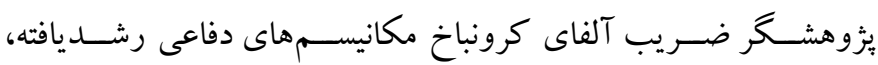

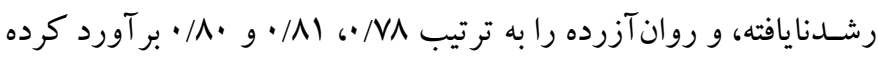

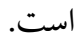
r. برسششنامه حس انسـجام. إين برسشنامه توسط آنتونووسكى در سال

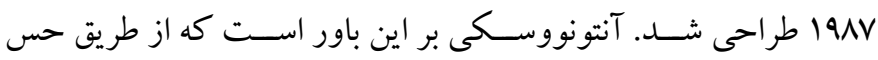

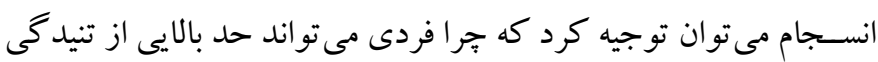

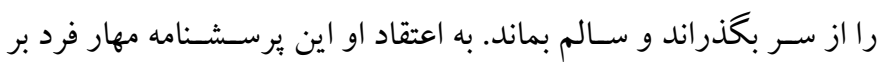

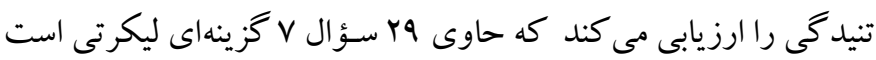

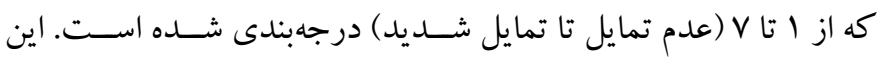

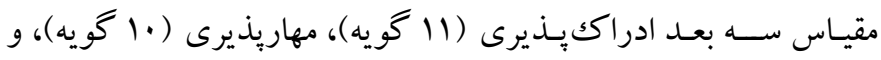

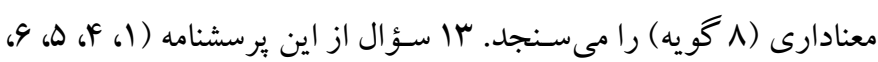

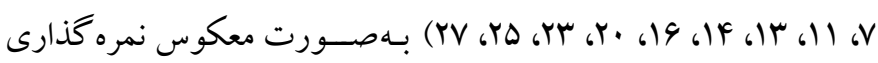

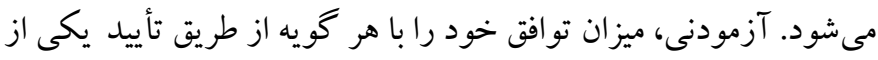

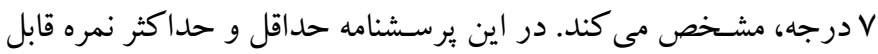

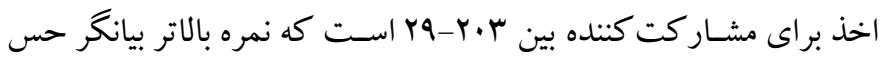

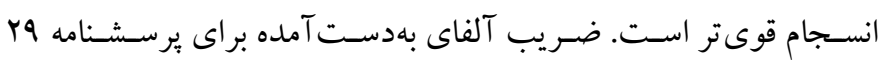

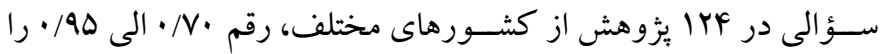

از والـدين كودكـان اختلـال طيف اوتيســم، ·ب نفر از والـدين كودكان

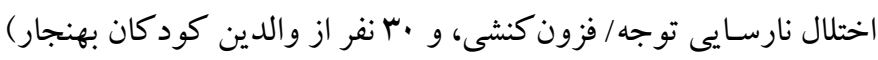

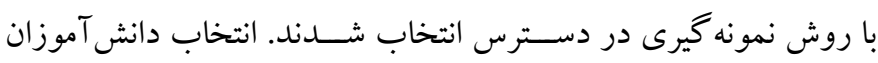

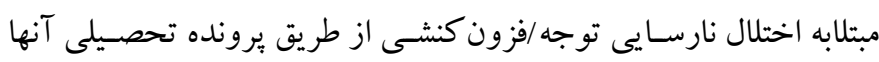

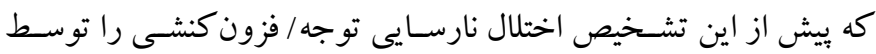

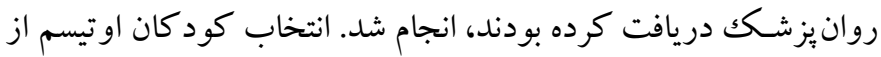

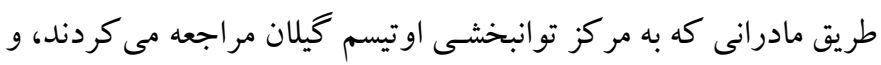

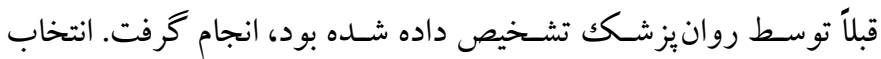

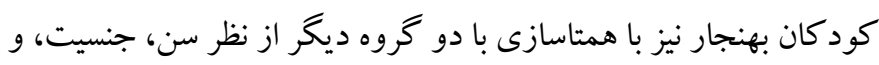

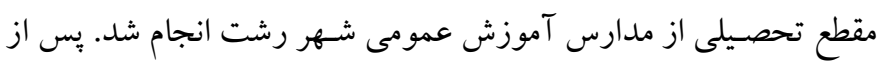

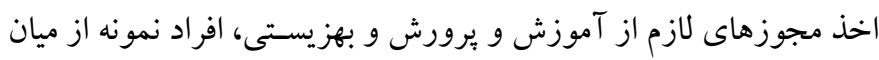

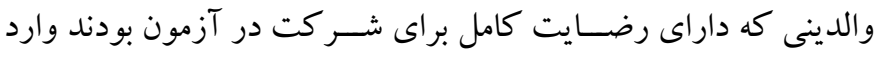
مطالعه شدند. از ملاككهاى ورود به مطالعه، مبتلا بودن كود كان به به اختلال

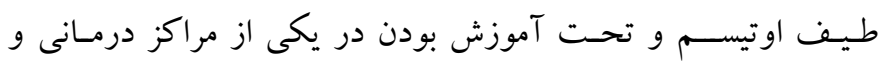

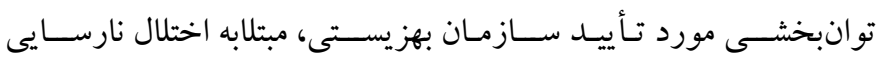

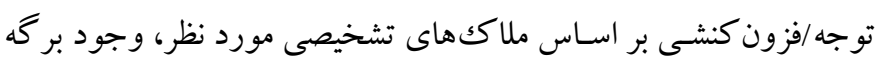
تشخيص اختلال توسط روانيزشك در يرونده كودكى، نداشتن اختلال

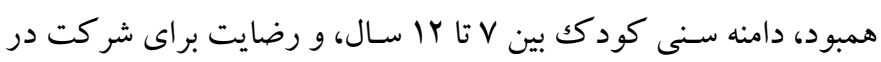

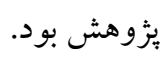

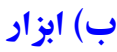
ا. برسشنامه مكانيسمهاى دفاعى': اين ابزار توسط آندروز و همكاران با هدف مقايسه مكانيسمهاى دفاعى در نمونه هاى بالينى و غيربالينى در سال

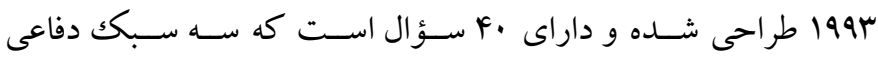

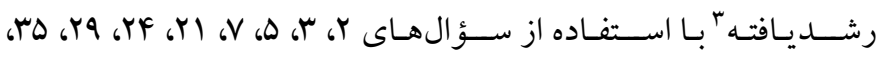

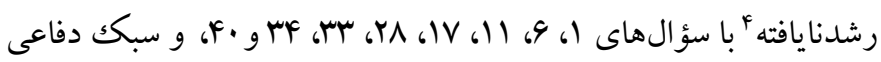
روان آزردهه (مابقى سـوالات) را مورد ارزيابى قرار مىدهد. سـؤهوال ها در

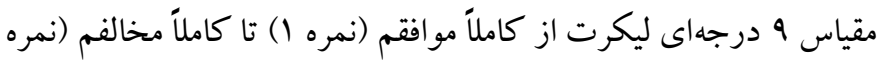

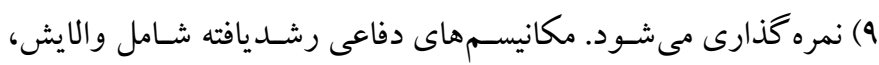

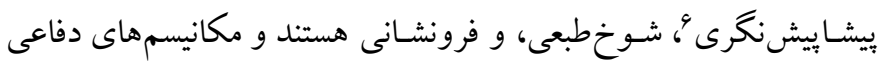

1. Defense Style Questionnaire

2. Androus

3. Developed

4. Undeveloped 
بدين ترتيب به آزمودنىها كفته شد كه اطلاعات آنان كاملاً محرمانه بوده

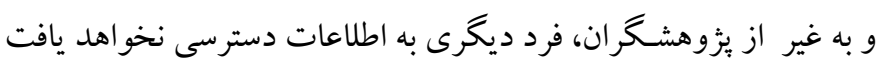

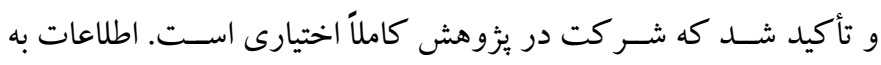

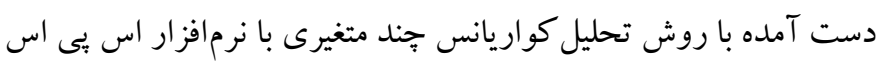
اس مورد تجزيهو تحليل قرار گرفت.

\section{يافتهها}

با توجه به هدف يُزوهش كه مقايسه انسجام روانى و مكانيسمهاى دفاعى

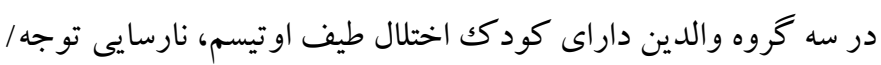
فزون كنشـى، و بهنجار بود در جدول ا ميانكين و انحر اف معيار نمرات

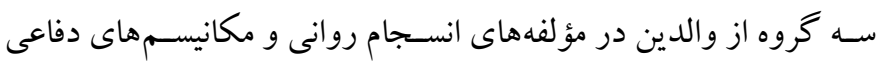

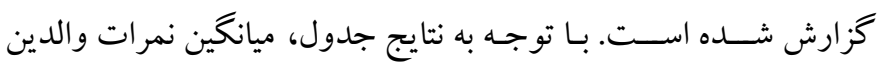

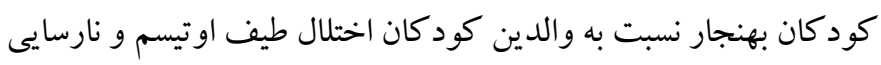

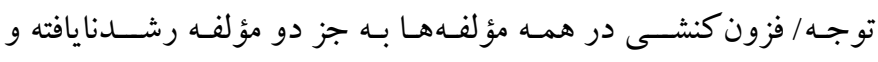

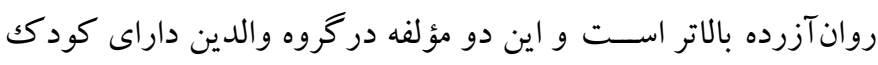

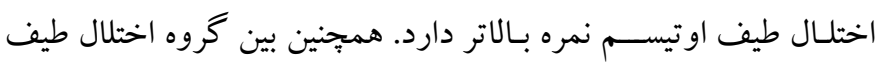

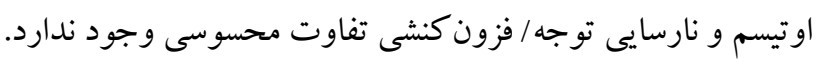

نشـان داد. ضـريب باز آزمايى بيانگر يايايى برسـشـنامه بود و نشـاندهنده

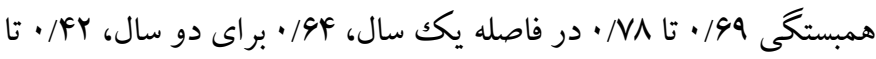

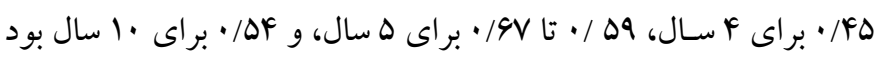

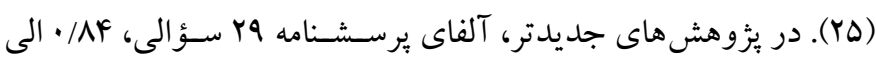

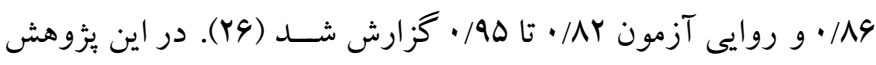

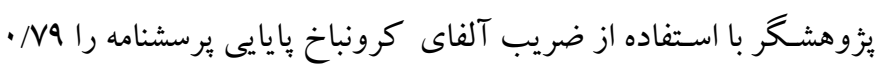
بر آورد كرده است. ج) روش اجرا: بِ از هماهنگگىهاى لازم با سـازمان آموزش و برورش

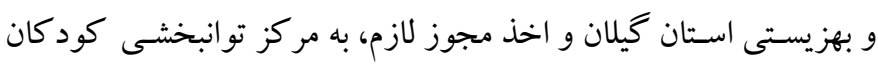

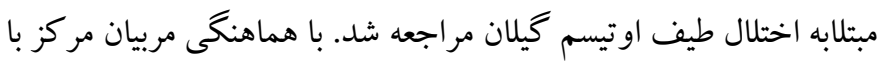

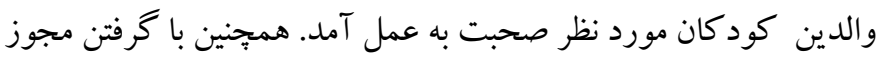

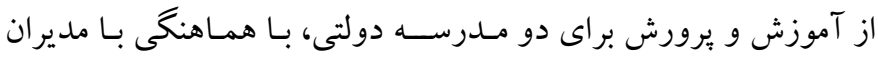

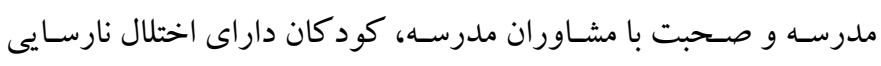

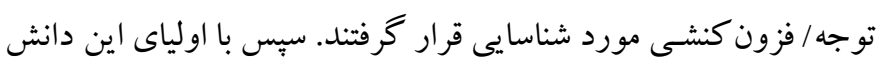

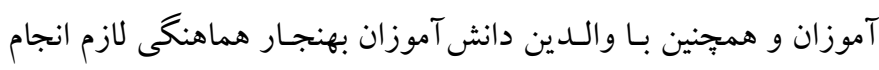

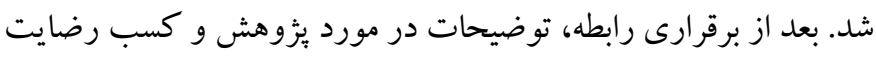

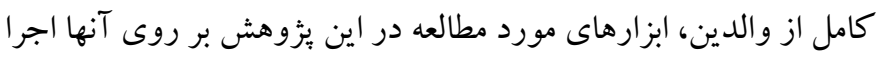

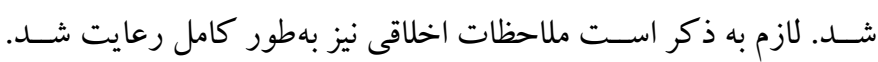

جدول ا: ميانكين، انحر اف معيار، نمرات آزمون انسجام روانى و مكانيسم دفاعى در والدين داراى كودكى بهنجار، نارسايى توجه/فزون كنشى، و طيف اوتيسم

\begin{tabular}{|c|c|c|c|c|c|c|c|c|}
\hline \multirow{2}{*}{\multicolumn{2}{|c|}{ آزمون كالموكروف-اسميرنف }} & \multicolumn{2}{|c|}{ اوتيسم } & \multicolumn{2}{|c|}{ فزون كنش } & \multicolumn{2}{|c|}{ بهنجار } & \multirow{2}{*}{ متغير } \\
\hline & & انحراف معيار & ميانكين & انحر اف معيار & ميانغين & انحراف معيار & ميانكين & \\
\hline$\cdot / \cdot v \Delta$ & .1 .94 & $0 / 94$ & $r \cdot / \Delta F$ & V/rr & $r q / r$. & $f / r q$ & $\mathrm{Fr} / \cdot \mathrm{r}$ & قابل دركك بودن \\
\hline$\cdot / \cdot \mathrm{VA}$ & $\cdot / \cdot v V$ & f/ar & $Y F / .4$ & $F / \Delta F$ & $r r / 9$. & $r / \cdot 1$ & $r V / v$. & كنترل يذيرى \\
\hline$\cdot / \cdot \Delta r$ & $\% \cdot v a$ & $r / \Lambda r$ & 11 & r/Ar & If & $r / M$ & $r Y / r$. & معنى دار بودن \\
\hline$\cdot / r \cdot$ &.$/ . \Delta \Delta$ & $\mid V / 11$ & $1 \cdot r / r q$ & $v / \pi \Delta$ & $91 / \pi /$ & $V / \backslash \Delta 1$ & $9 \pi / 4 r$ & رشدنايافته \\
\hline.$/ . \Delta F$ & $\cdot / \cdot \Lambda$ & $r / \cdot r$ & $\mathrm{IV} / \mathrm{VV}$ & $r / 99$ & $r \mid / r q$ & $r / \Delta \Delta$ & ro & رشديافته \\
\hline$\cdot / r \cdot$. & $\% \cdot \Delta v$ & $\Delta / \wedge \varphi$ & $r F / 19$ & $\Delta / M$ & rI/৭9 & r/Ar & $r / . r$ & روان آزرده \\
\hline
\end{tabular}

معنـادارى آماره آن بود كه نشــان مىداد ييشفرض همخنى واريانسها رعايت شده است (ه) • (p).

آزمون امباكس جهت بررسى شرط همخنى ماتريس هاى واريانس كوواريانس به عمل آمد. نتيجه امباكس براى متغير انسـجام روانى برابر با

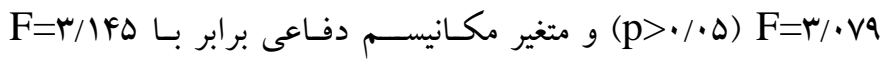
(p>••• بود كه نشـان داد شـرط همخنى واريانس -كوواريانس برقرار
قبل از ارائه نتايج تحليل آزمون واريانس، بيشفرضهاى آزمونهاى يـار امتريـك مورد ســنجش قرار كرفـت. بر همين اســاس نتايج آزمون كالمو گروف-اسـميرنف بيانكر آن بود كه ييشفرض نرمال بودن توزيع نمونهاى دادهها برقرار اسـت (ه•/p> • بيشفرض همخنى واريانس نيز توســط آزمون لوين مورد ســنجش قرار گرفت كه نتايج آن بيانكر عدم 
مؤلفههاى انســام روانى نتايج تحليل واريانس در جدول ب ارائه شــده

اســت. نتيجـه آزمون لـامبـداى ويلكز براى متغير انسـجام روانى برابر با

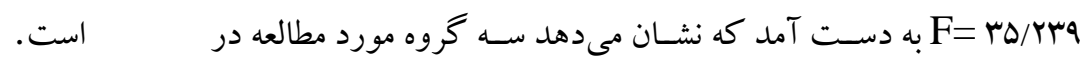

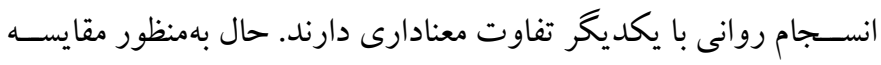

جدول r: نتايج تحليل واريانس روى ميانغين مؤلفههاى آزمون انسجام روانى در سه كروه

\begin{tabular}{|c|c|c|c|c|c|c|}
\hline مجذور اتا & سطح معنىدارى & $\mathbf{F}$ & ميانگين مجذورات & درجه آزادى & مجموع مجذورات & متغير وابسته \\
\hline.$/ 499$ &.$\cdot \cdot 1$ & Fr/VQq & $|F \wedge 9 / 9| \mid$ & r & rQVQ/Arr & قابل دركك بودن \\
\hline$\cdot / \mathrm{NIA}$ & 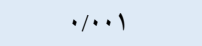 & $11 \cdot /$ Vrr & $199 \cdot / r .$. & r & $\operatorname{rar} \cdot 19 .$. & مهاريذيرى \\
\hline$\cdot / \Delta \mathrm{V} \mid$ & $\% \cdot \cdot 1$ & $\Delta N / \cdot 1 f$ & FqV/FVA & r & $99 \% / ৭ \Delta ४$ & معنى دار بودن \\
\hline$\cdot / N 11$ & $\%$ & $1.9 / 9 \mathrm{FF}$ & $1 \cdot V r \cdot 1 \cdot r r$ & r & rIFF. $/ .9 \mathrm{~V}$ & نمره كل انسجام روانى \\
\hline
\end{tabular}

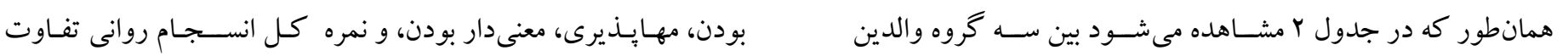

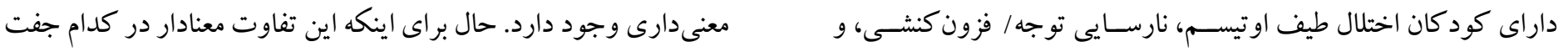

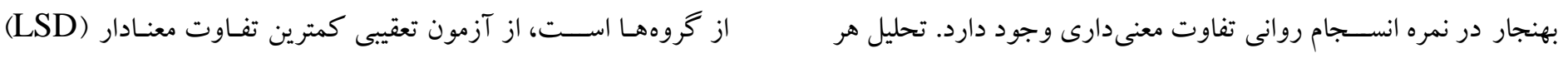

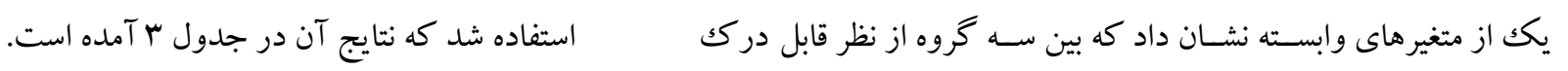

جدول זّ: نتايج آزمون كمترين تفاوت معنادار (LSD)

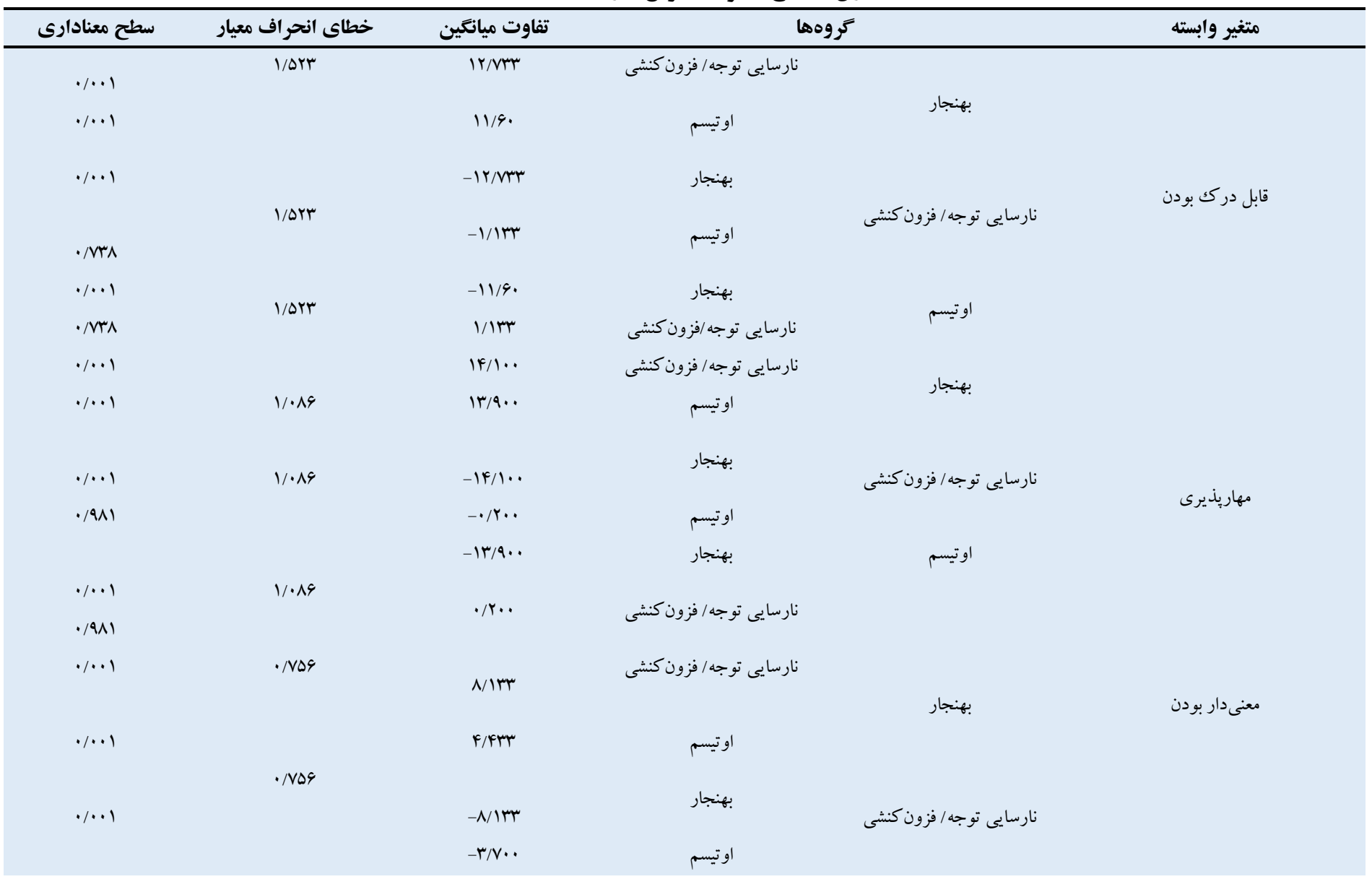




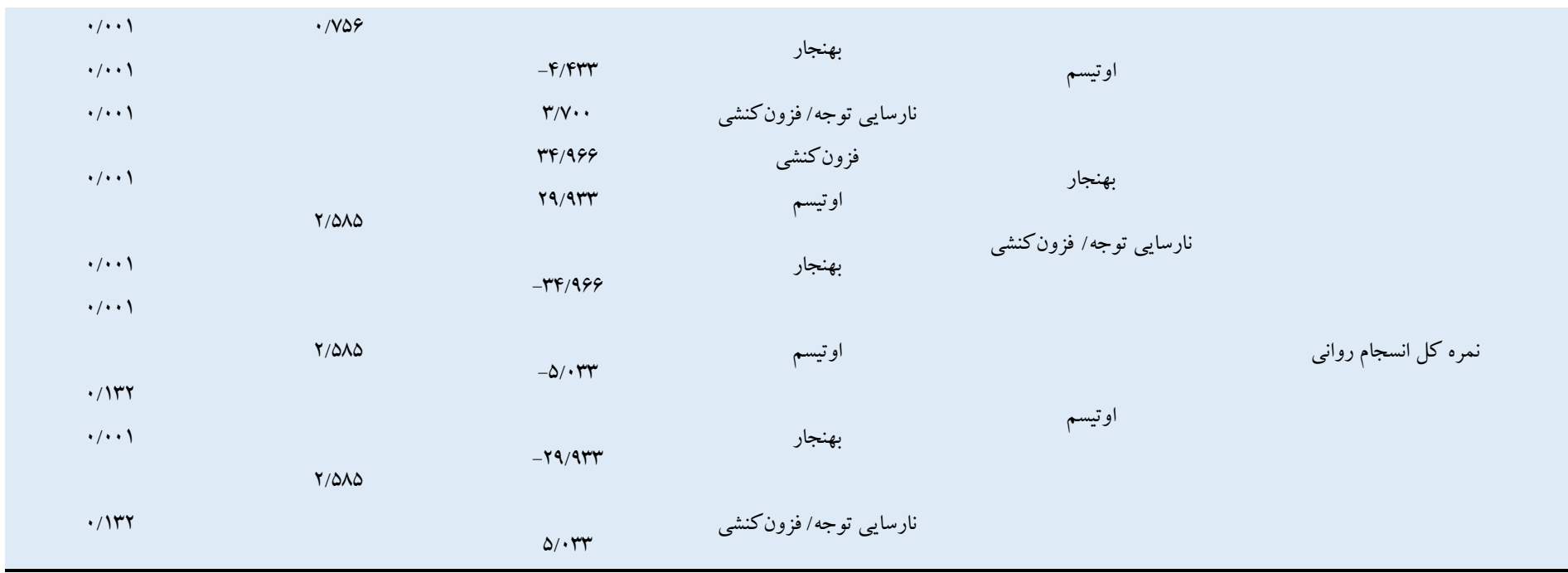

نتايج مقايسـه سـه كروه در مكانيسـمهاى دفاعى رشـد نايافته، رشديافته، و

درباره مقايسه سه گروه از والدين مورد مطالعه در مكانيسمهاى دفاعى

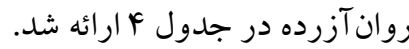

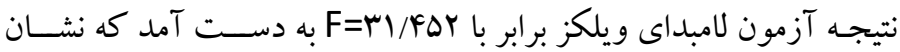
مى دهد بين گروهها در مكانيســمهاى دفاعى تفاوت معنادارى وجود دارد.

جدول ع: نتايج تحليل واريانس روى ميانغين مؤلفههاى آزمون مكانيسم دفاعى در سه تروه

\begin{tabular}{|c|c|c|c|c|c|c|}
\hline مجذور اتا & سطح معنىدارى & $\mathbf{F}$ & ميانكين مجذورات & درجه آزادى & مجموع مجذورات & متغير وابسته \\
\hline$\cdot 19 \mathrm{VY}$ & $\cdot / \cdot 1$ & $\wedge 9 / 11 \vee$ & $|r||r /| \ldots$ & r & TFYYG/Y.. & رشدنايافته \\
\hline$\cdot 10 \cdot 9$ &.$\cdot \cdot 1$ & $P \Delta / \cdot \Delta q$ & FIN/NT & r & NHG/YgV & ر رشديافته \\
\hline$\cdot / 4 v$ &.$/ \cdot 1$ & HN/DAF & 1. VF/gMr & r & rIFQ/YGV & روان آزرده \\
\hline
\end{tabular}

وجود دارد. بـهمنظور فهم تفـاوت گروههاى ســهـ گانه اين زئوهش در آزمون مكانيسم دفاعى، از آزمون تعقيبى كمترين تفاوت معنادار استفاده شده است كه نتايج به دست آمده از آن در جدول هارائه شده است.
همـان طور كـه در جدول f مشــاهده مىشــود بين ميانكين آزمون مكانيسـم دفاعى در بين سـه گروه تفاوت معنى دارى وجود دارد. تحليل هر يـك از متغيرهاى وابســته نشــان مى دهد كه: بين ســهـ گروه از نظر مكانيسـم دفاعى رشـدنايافته، رشـديافته، و روان آزرده تفاوت معنى دارى

جدول ه: نتايج آزمون كمترين تفاوت معنادار (LSD)

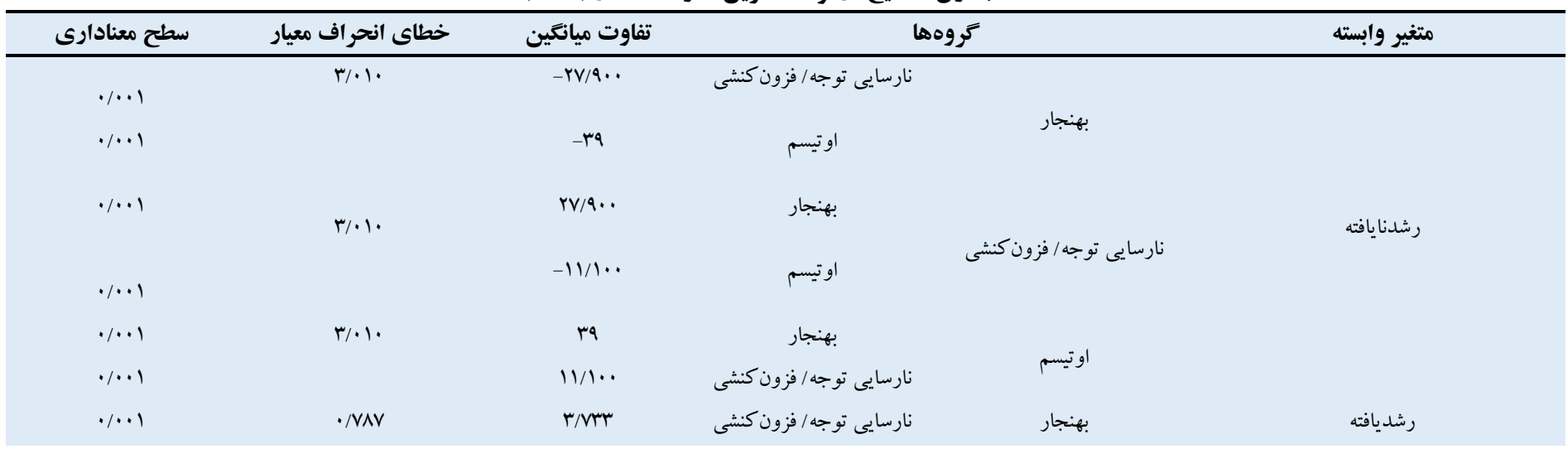




\begin{tabular}{|c|c|c|c|c|c|}
\hline $\begin{array}{l}. / ., 1 \\
. / .1\end{array}$ & $\cdot /$ VAV & $\begin{array}{l}\text { V/\&GV } \\
-r / N T r\end{array}$ & اوتيسم & نارسايى توجه/ فزون كنشى & \\
\hline$\cdot / \cdot \cdot 1$ & & r/NTr & اوتيسم & & \\
\hline & $\cdot /$ VAV & $-V / \& 4 \mathrm{~V}$ & بهنجار & اوتيسم & \\
\hline $\begin{array}{l}. \cdot .1 \\
. / .1\end{array}$ & & - & نارسايى توجه/فزون كنشى & & \\
\hline$\cdot / \cdot \cdot 1$ & $1 / r q 4$ & $\begin{array}{l}-\Lambda / 9 T Y \\
-11 / r 9 V\end{array}$ & نارسايى توجه/فزون كنشى & بهنجار & روانآزرده \\
\hline$\cdot / . \cdot 1$ & $1 /$ Tar & $\begin{array}{l}\text { N/qRT } \\
-r / 4 \pi T\end{array}$ & اوتيسم & نارسايى توجه/ فزون كنشى & \\
\hline $\begin{array}{l}. / . \cdot 1 \\
. / . \cdot 1 \\
. / .1\end{array}$ & $1 /$ Tar & $\begin{array}{l}11 / \pi / V \\
\text { r/FTr }\end{array}$ & نارسايى توجه/فزون كنشى بهنجار & اوتيسم & \\
\hline
\end{tabular}

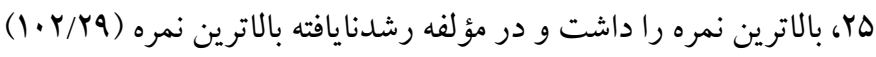

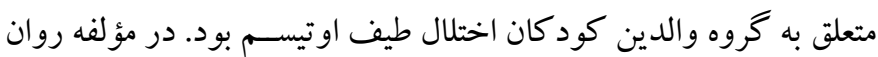

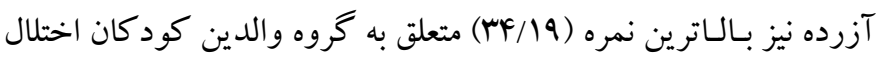

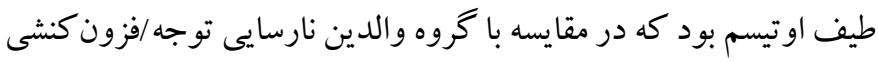

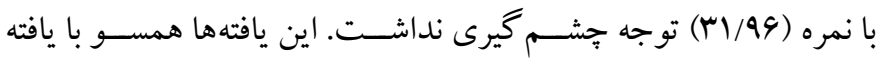

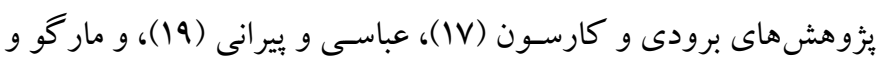
همكاران (·r) است كه نشان دادهاند والدين كود كان استثنائى در مقايسه

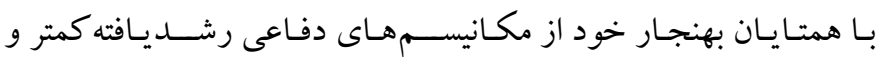
مكانيسمهاى رشدنايافته و روان آزرده بيشترى برخوردارند. همجنين نتايج

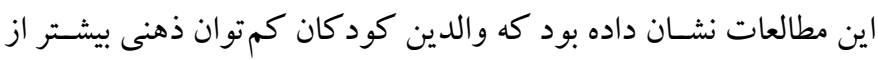

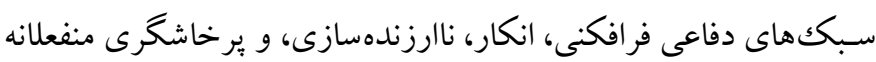

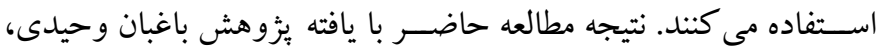

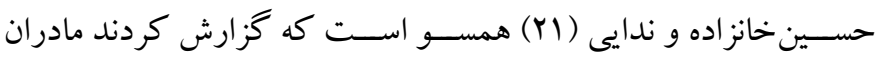
كو دكان اوتيسم از مكانيسممهاى دفاعى نابالغ استفاده مى كنند. در تبيين

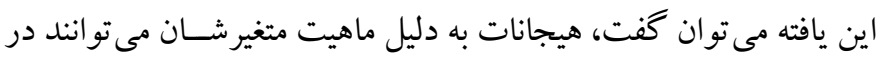

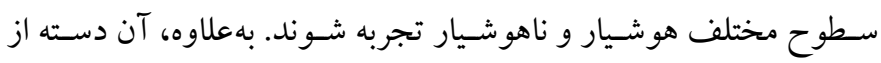
هيجانات كه منبع اضطر اب هستند توسط مكانيسمهاى دفاعى به ناهوشيار رانده مىشـوند. از طرفى بايد توجه داشت كه مكانيسمهاى دفاعى نيز در

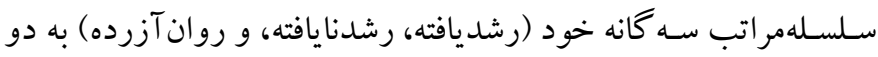

بر اســاس نتايج جدول ه مى توان مشــاهده كرد كه گروه بهنجار به

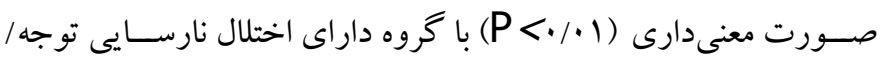
فزون كنشــى، و اختلال طيف اوتيســم تفاوت دارد و همجينين بين گرووه

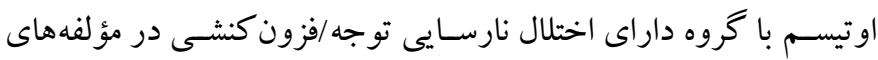

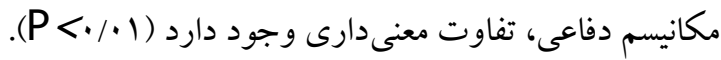

\section{بحث و نتيجه كيرى} يُزوهش حاضـر با هدف مقايسه انسجام روانى و مكانيسمهاى دفاعى در

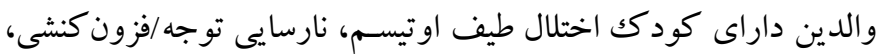
و بهنجار انجام شـد. يافتها نشـان داده است بين گرووهاى والدين داراى كود كان بهنجار با والدين داراى كود كان اختلال طيف اوتيسم و نارسايى لته توجه / فزون كنشى در نمرات مكانيسمهاى دفاعى و انسجام روانى تفاوت

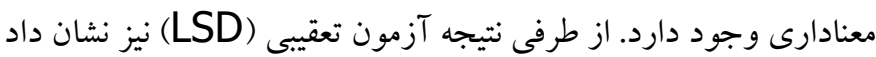

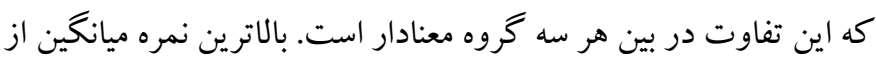

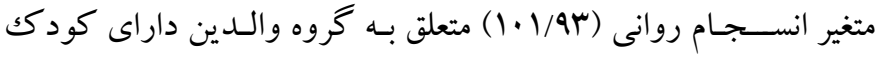

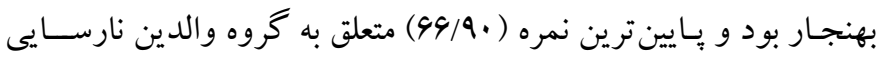

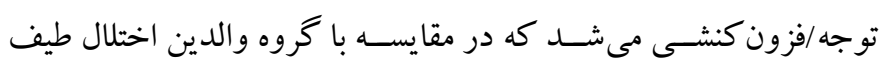

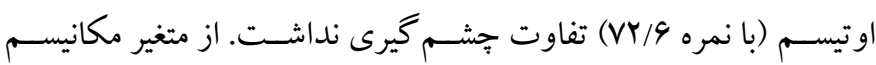

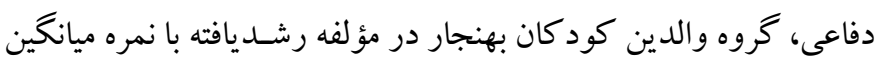


اوتيسـم و نارسـايى توجه / فزون كنشى در نمرات انسـجام روانى تفاوت

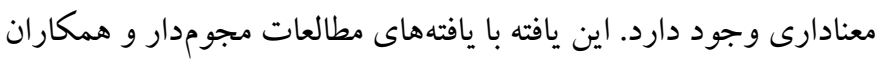

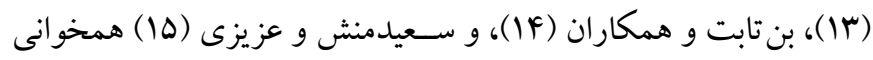

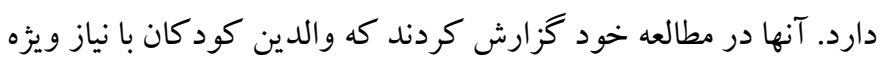

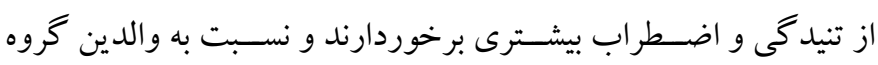
كود كان بهنجار، هيجانى تر و داراى تنش عصبى بيشترى هستند.

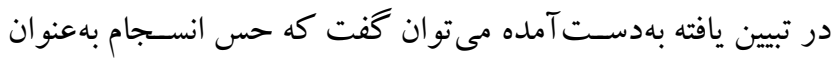

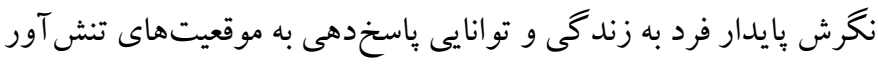

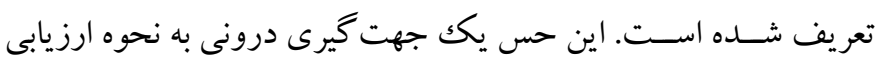

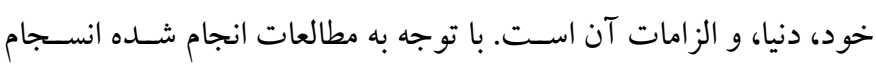

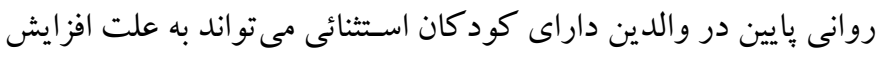

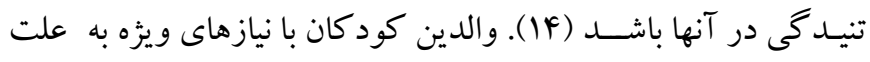

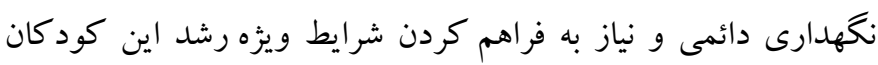

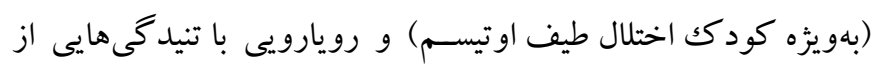

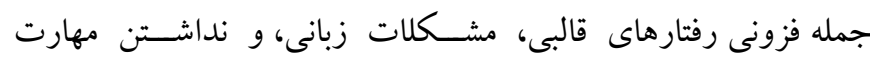
مراقبت از خود در اين كود كان ، كاركرد طبيعىشـان تضعيف مى شودو؛ به همين دليل اسـت كه ميانگين آسـيبهاى روانى در والدين

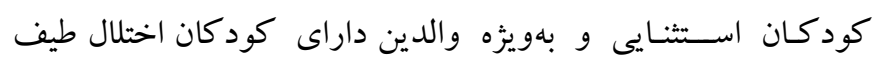
اوتيسم بالاتر از والدين داراى كودكك بهنجار است (r).

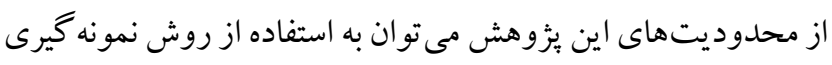

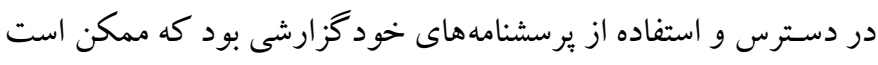

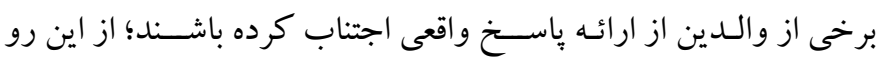

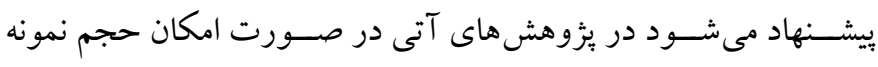
بهصـورت تصـادفى انتخاب شـود و علاوه بر برسـشــنامهها از مصـاحبه

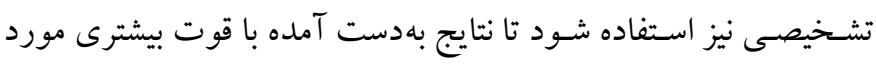

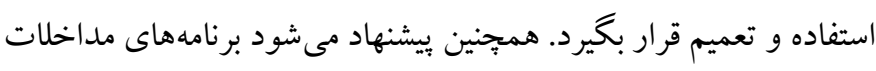

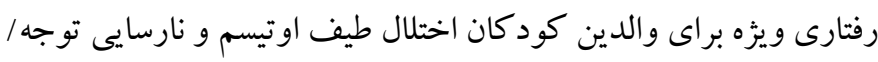

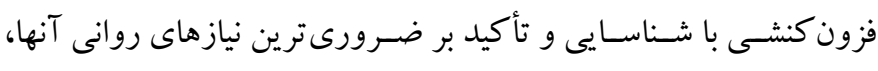

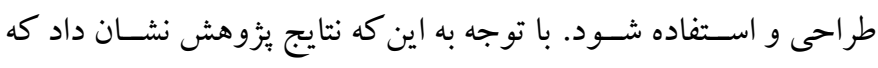

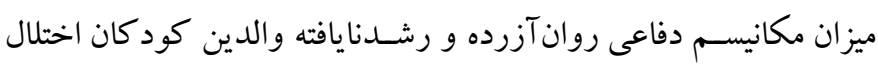

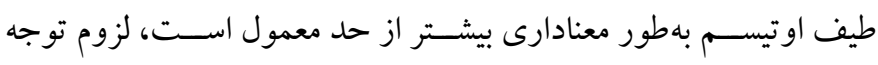

دسته انطباقى (رشديافته) و غير انطباقى (رشد نايافته و روانآزرده) تقسيم

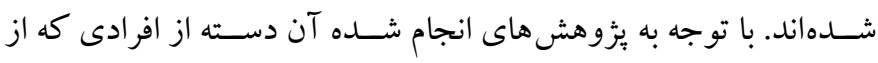

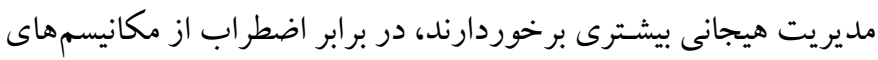

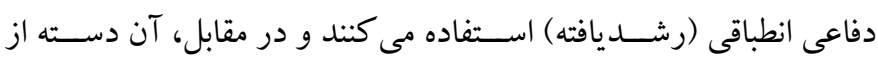

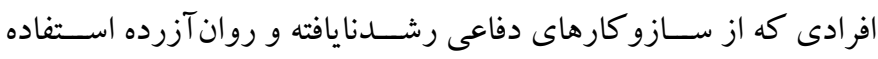

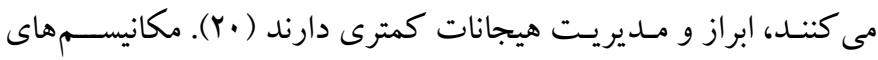
دفاعى، اغلب راهكارهايى براى تحريف واقعيت هستند (اين تحريف در

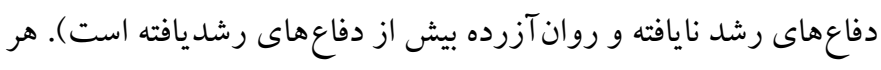
جه ميزان تحريف شـناختى ناشسى از به كار گيرى مكانيسـم دفاعى بيشـتر

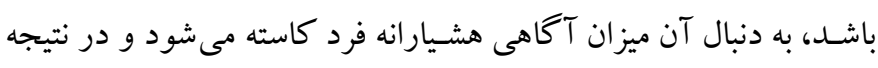

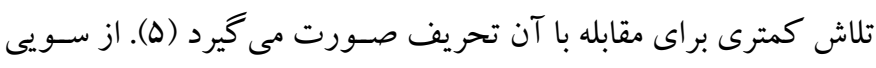

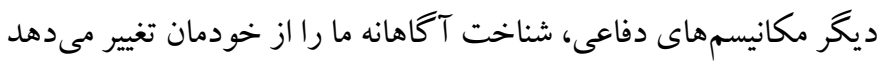

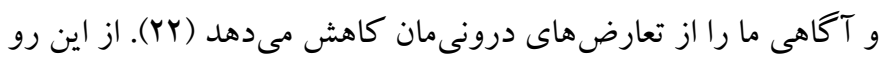

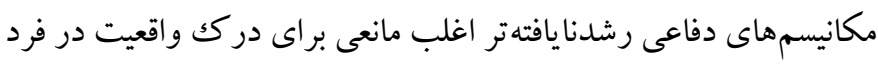

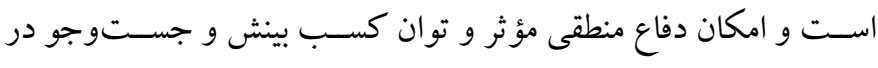

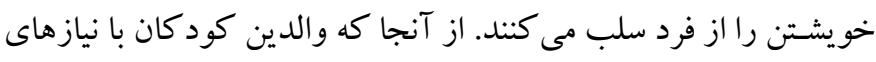

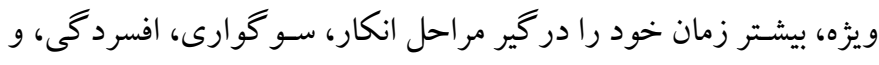

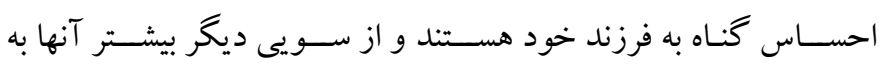

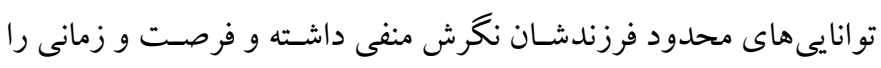

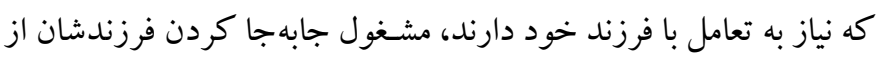

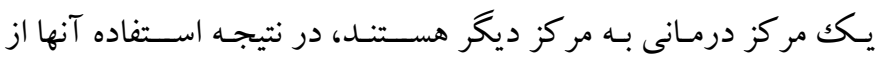

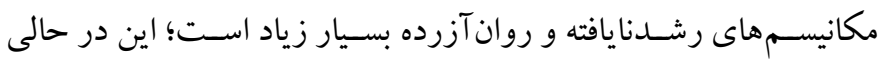
است كه مكانيسمهاى دفاعى مطلوب، شناخت آكاهانه ما را از خود تغيير

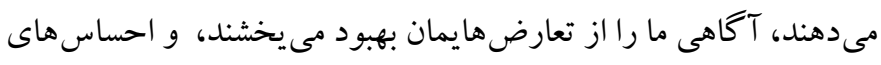

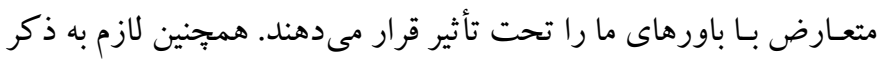

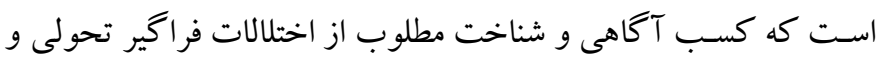

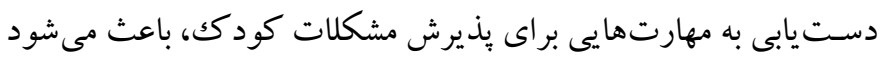

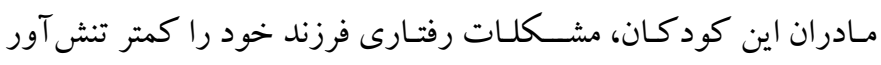

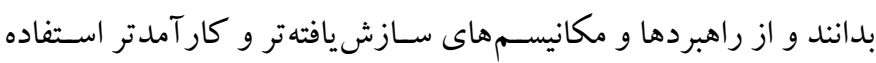
كنند (YV)

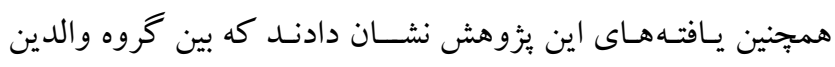

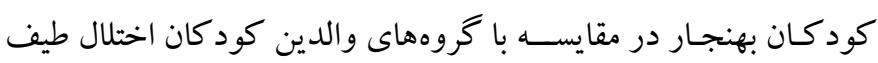


مسئولين اداره بهز يستى مخصوصاً كارشناس هسته مشاوره كه هماهنكى با مركز

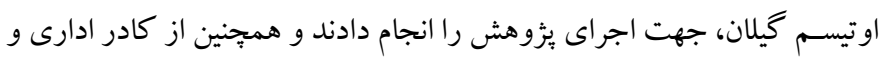

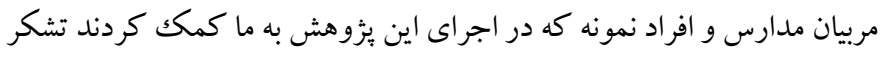

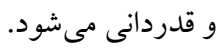
تضـاد منافع: يادآور مى شـود اين يُزوهش براى نويسـند كان هيج گونه تضـاد منافعى نداشته است.
هرجه بيشــر به طر احى راهكارهاى مناسـب براى افز ايش ميز ان سـلامت روان والدين اين كود كان احساس مى بـود.

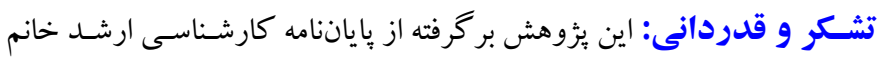

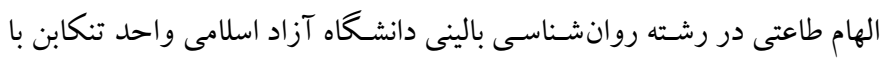

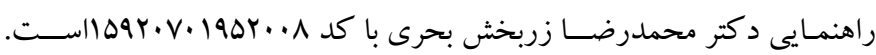
همجنين مجوز اجر اي آن بر روى افراد نمونه از سوى اداره بهزيستى شهر رشت بهر

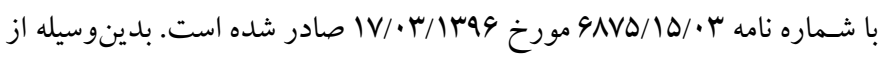




\section{References}

1. McConachie H, Diggle T. Parent implemented early intervention for young children with autism spectrum disorder: a systematic review. J Eval Clin Pract. 2007; 13(1): 120-129. [Link]

2. Arjmand Nia AA, Afrooz GA, Nami MS. The comparison between marital satisfaction, emotional stress cognitive social support in parents having mentally-impaired children and parents having normal children. Exceptional Education Journal. 2013; 3(116): 5-15. [Persian]. [Link]

3. Shiralinia K, Abdollahi Musavi H, KHojastemehr R. The effectiveness of group acceptance and commitment therapy (ACT)-based training on parenting stress and psychological flexibility in mothers of children with autism spectrum disorder. Psychology of Exceptional Individuals. 2018; 7(28): 21-44. [Persian]. [Link]

4. Beirami M, Hashemi Nosrat Abad T, Movahedi Y, Besharat R, Kohpeima S. Comparison of sleep quality components in parents of autistic, mentally retarded, and normal children. Psychology of Exceptional Individuals. 2014; 4(13): 29-46. [Persian]. [Link]

5. Dabrowska A, Pisula E. Parenting stress and coping styles in mothers and fathers of pre-school children with autism and Down syndrome. J Intellect Disabil Res. 2010; 54(3): 266-280. [Link]

6. Moshkani M, Mirabedini SH, Mallah M. The relationship between stress and coping styles with adaptive behavior of mothers of children with autism spectrum disorder. Exceptional Education Journal. 2017; 2(145): 21-28. [Persian]. [Link]

7. Seidman LJ. Neuropsychological functioning in people with ADHD across the lifespan. Clin Psychol Rev. 2006; 26(4): 466-485. [Link]

8. Madani S, Alizadeh $\mathrm{H}$. Executive functions and effective strategies to improve them in students with attention deficit hyperactivity disorder. Exceptional Education Journal. 2018; 4(153): 55-63. [Persian]. [Link]

9. Yousefi N, Naimi GH, Ghaedniyajahromi A, Mohammadi H, Farmani Shareza SH. A comparison of adhd and oppositional behavioral and conduct disorders in elementary students with learning disabilities and normal students. Journal of Learning Disabilities. 2013; 3(18): 129-147. [Persian]. [Link]

10. Yousefia S, Soltani Far A, Abdolahian E. Parenting stress and parenting styles in mothers of ADHD with mothers of normal children. Procedia Soc Behav Sci. 2011; 30: 1666-1671. [Link]
11. Lin L-Y, Orsmond GI, Coster WJ, Cohn ES. Families of adolescents and adults with autism spectrum disorders in Taiwan: The role of social support and coping in family adaptation and maternal well-being. Res Autism Spectr Disord. 2011; 5(1): 144-156. [Link]

12. Fosco WD, Sarver DE, Kofler MJ, Aduen PA. Parent and child neurocognitive functioning predict response to behavioral parent training for youth with ADHD. Atten Defic Hyperact Disord. 2018; 10(4): 285-295. [Link]

13. Majumdar M, Da Silva Pereira Y, Fernandes J. Stress and anxiety in parents of mentally retarded children. Indian J Psychiatry. 2005; 47(3): 144-147. [Link]

14. Ben Thabet J, Sallemi R, Hasïri I, Zouari L, Kamoun $\mathrm{F}$, Zouari N, et al. Répercussions psycho-affectives du handicap de l'enfant sur les parents. Arch Pediatr. 2013; 20(1): 9-16. [Link]

15. Saeedmanesh M, Azizi M. The effectiveness of intervention of treatment based on acceptancecommtment therapy on the rate of parent,s acceptance of autistic children and their denial-defense mechanism. Middle Eastern Journal of Disability Studies. 2017; 7: 47. [Persian]. [Link]

16. Ganji M, Mohamadi J, Tabrizian SH. Comparing emotional regulation and defense mechanisms in mothers of students with and without learning disabilities. Journal of Learning Disabilities. 2013; 2(36): 54-72. [Persian]. [Link]

17. Brody S, Carson CM. Brief report: Self-harm is associated with immature defense mechanisms but not substance use in a nonclinical Scottish adolescent sample. J Adolesc. 2012; 35(3): 765-767. [Link]

18. Kelishadi F, Yazdkhasti F. Impact of perception of parental rejection-acceptance and control on moral intelligence and distress tolerance. Strategy for Culture. 2016; 9(33): 155-169. [Persian]. [Link]

19. Abbasi M, Pirani Z. Pathological defense mechanisms of parents of deaf children and children with intellectual disabilities: a search for corrective solutions. Middle Eastern Journal of Disability Studies. 2017; 7: 17. [Persian]. [Link]

20. Margo GM, Greenberg RP, Fisher S, Dewan M. A direct comparison of the defense mechanisms of nondepressed people and depressed psychiatric inpatients. Compr Psychiatry. 1993; 34(1): 65-69. [Link]

21. Baghban Vahidi M, Hossein Khanzadeh AA, Nedaee $\mathrm{N}$. The impact of training mothers of autistic children for effective communication skills on social skills improvement in autistic children. Middle Eastern 
Journal of Disability Studies. 2017; 7: 44. [Persian]. [Link]

22. Khoushabi K, Farzad Fard SZ, Kakasoltani B, Pouretemad Hamid R, Nikkhah HR. Coping strategies and stress in mothers with autistic children in comparison with mothers with normal children. Journal of Family Research. 2010; 6(21): 87-97. [Persian]. [Link]

23. Besharat MA, Shahidi S. What is the relationship between alexithymia and ego defense styles? A correlational study with Iranian students. Asian J Psychiatr. 2011; 4(2): 145-149. [Link]

24. Ranjbari T, Besharat MA, Pourhossein R. The mediating role of defense mechanisms in the relationship between attachment pathologies and the symptoms of depression and anxiety. Journal of
Developmental Psychology. 2017; 14(53): 15-27. [Persian]. [Link]

25. Antonovsky A. The structure and properties of the sense of coherence scale. Soc Sci Med. 1993; 36(6): 725-733. [Link]

26. Bergstein M, Weizman A, Solomon Z. Sense of coherence among delusional patients: prediction of remission and risk of relapse. Compr Psychiatry. 2008; 49(3): 288-296. [Link]

27. Ahmadi A, Raeisi Z. The effect of acceptance and commitment therapy on distress tolerance in mothers of children with autism. Quarterly Journal of Child Mental Health. 2018; 5(3): 69-79. [Persian]. [Link] 